\title{
Stanisław August i powracające Muzy. Rzecz o panegirycznym wierszu elekcyjnym
}

\author{
Aleksandra Norkowska
}


nAPIS Seria IV 1998

\section{Aleksandra Norkowska}

\section{Stanisław August i powracające Muzy. Rzecz o panegirycznym wierszu elekcyjnym ${ }^{1}$}

Jedni wołali: «Zgoda, zgoda, mamy króla Piasta», drudzy krzyczeli: «Wiwat król Stanisław August, wiwat Piast», trzeci: «Nie chcemy Piasta — precz z Piastem», a byli i tacy $z$ Wielkopolanów, którzy się wzięli do szabel, jednakże większość za Stanisławem przemogła. Bo kto miał być królem, i z czyjej rady, i za czyim wpływem, rzeczy wprzód były ukartowane, i tylko powierzchowna ceremonia dopełnić się musiała. Zginęło dwóch szlachty, a kilku porąbano niesfornych. Zresztą kotły, trąby, muzyka i strzały moździerzowe zagłuszyły wszystko ${ }^{2}$

— w ten oto sposób Tadeusz Konopka h. Nowina — na podstawie wspomnień swego ojca Józefa — oddał atmosferę panującą in loco electorali 7 IX 1764 roku. Tak odmienne reakcje szlachty oraz wypowiedzi opozycjonistów przedstawiające polskiego władcę jako jurgieltnika carycy (a co za tym idzie, marionetkowego władcę) stały się w rękach twórców narzędziem perswazji kształtującym ideową postawę obywateli. Przypomnijmy w tym miejscu, że ta różnorodna prezentacja osoby króla - wyłaniająca się z poetyckich przekazów już w dniu elekcji - towarzyszyla Poniatowskiemu przez cały okres panowania ${ }^{3}$.

\footnotetext{
1 Tekst ten stanowi fragment rozważan, których celem jest ukazanie poetyckiego portretu Stanisława Augusta Poniatowskiego w literackich wypowiedziach powstalych z okazji elekcji.

2 T. Konopka, Historia Domu Naszego. Raptularz z czasóu' Stanistaura Augusta, opr. M. Konopka, Warszawa 1993, s. 73. O głównym bohaterze pamiętników, Józefic Konopce, jako o reprezentancie polskiego klienteryzmu zob. K. Zienkowska, Stanistau August Poniatouski, Wrocław 1998, s. 46-47. Dodajmy tylko, że w większości przekazów przedstawia się wybór Poniatowskiego na króla jako jednogłośny.

${ }^{3}$ Antykrólewskie wystąpienia nasiliły się w czasach konfederacji radomskiej i barskiej. Spod pióra anonimowego konfederata wyszły m.in. takie oto słowa przywołujące obraz elekcji: „Gdy przywdział [Stanisław August] koronę - szlachta w krzyk, w panice". (Gauędka przy kominie [b. d. ], egz. Archiwum Państwowego
} 
Celem szkicu jest ukazanie panegirycznego portretu ostatniego monarchy Rzeczypospolitej w jednym z utworów należących do nurtu prokrólewskiej poezji elekcyjnej ${ }^{4}$. Interesuje nas sposób zaprezentowania głównego bohatera wydarzeń w podwarszawskiej Woli w kontekście okolicznościowych wypowiedzi powstałych z okazji wyniesienia na tron stolnika litewskiego. Naszym zadaniem jest również odtworzenie zastosowanych przez autora wątków i motywów budujących pochwałę nowego władcy oraz wskazanie argumentów laudacyjnych i powiązań wypowiedzi poetyckiej z tradycją retoryczną.

Na wieść o szczęśliwie zakończonej elekcji w różnych stronach Rzeczypospolitej odprawiano nabożeństwa dziękczynne, głoszono okolicznościowe oracje, a zorganizowane w wielu miejscowościach festyny, fajerwerki, iluminacje i widowiska teatralne uświetniały elementy architektury okazjonalnej. Tendencję laudacyjną wyrażały również — przepełnione radością - utwory poetyckie oddane niejednokrotnie pod patronat jednej tylko Muzy bądź też całego grona helikońskich bogiń towarzyszących Apollinowi. Twórcy elekcyjnych panegiryków — na wzór najdawniejszych dzieł antycznych — rozpoczynali swą „pieśń od Muz Helikońskich”, gdyż to one - jak czytamy w Teogonii Hezjoda, pierwszym tekście wymieniającym imiona dziewięciu bogiń - obdarzały autora „boskim głosem”, aby mógł sławić „to, co będzie, / i to, co niegdyś było”. Opiewano więc przymioty Stanisława Augusta i prześcigano się w rozsławianiu dnia, w którym obrano go królem. Zarówno bowiem osoba nowego elekta, jak i zdarzenie, do którego doszło w podwarszawskiej Woli wymagały najwyższej pochwały. Obecność muz w czasie powstawania dzieła literackiego, którego celem było rozsławienie imienia nowego monarchy, zdawała się być niezbędna. Pieśń bowiem stworzona z inspiracji „złotem uwieńczonych” córek „pięknowłosej Mnemosyne” („Pamięci”), Tytanki, i olimpijskiego władcy ${ }^{5}$ - zapewnić miała bohaterowi nieśmiertelność. Literacka Rzeczpospolita, chcąc godnie powitać króla - Piasta, oczekiwała ze zniecierpliwieniem przybycia parnaskiej dziewicy. Ona to bowiem wesprzeć miała poetycką działalność sług Apollina.

Nie sposób nie zauważyć, że autorzy tekstów ogłoszonych drukiem w roku powołania Poniatowskiego na tron wskazywali na pewną opieszałość, jaka towarzyszyła bogini sławy i nieśmiertelności w powrocie na polski Helikon. Nie znany autor utworu zatytułowanego

w Krakowie, Teki Antoniego Schneidra 47. Przytoczmy również słowa zawarte we francuskiej powieści z tego samego, nieprzyjaznego królowi czasu: „[...] panowanie zacznie od świętowania i tak będzie postępowal dalej". (J.-P. Marat, Les Aventures du jeune comte Potowski, cyt. za: F. Rosset, Drzewo Kraków. Mit polski w literaturze francuskiej 1573-1896, przekł. autoryz. K. Błoński, Kraków 1997, s. 127).

${ }^{4}$ Warto przypomnieć już na początku naszych rozważań wypowiedź Janusza Tazbira dotyczącą tradycji i historii wolnych elekcji: „[...] niemal wszyscy wladcy elekcyjni rozpoczynali swoje rządy od nastrojów entuzjazmu, poparcia dla nowego króla i wielkich nadziei, kończyli zaś w atmosferze nieukrywanej ulgi, że oto wreszcie nadszedt kres jego panowania". (J. Tazbir, Geneza i skutki wolnych elekcji, [w:] Elekcje królów polskich w' Warszawie na Woli 1575-1764. Upamiętnienie pola elekcyjnego w 400-lecie stoleczności Warszawy, pod red. M. Tarczyńskiego, Warszawa 1997, s. 20).

${ }^{5}$ Por. Z. Kubiak, Mitologia Greków i Rzymian, Warszawa 1997, s.145-147, 171. 
Carmen Anacreonticum ${ }^{6}$ (napisanego po łacinie, grecku i po polsku) wyrażając radość z powodu pokojowo zakończonego wyboru nowego monarchy, zwrócił się jednocześnie do Muzy z zapytaniem:

Czemu niechybkim pędem

Tu z sobą wszystko znosisz,

A z swoim się urzędem

Sama do nas nie wprosisz?

Zacytowane powyżej pytanie jest charakterystyczne dla genus demonstrativum. Użycie tej figury myśli służy wyeksponowaniu celu wypowiedzi i określeniu głównej problematyki. Należy zauważyć, że jednym z argumentów, które miały nakłonić córę Diosa do zmiany zachowania było, lakoniczne co prawda, przywołanie przeszłości. Autor przekonywal, że Rzeczpospolita jest w stanie zapewnić bogini korzystne warunki i właściwą opiekę również w czasach mu współczesnych:

\section{Porzuciwszy Miasteczko \\ Rzeczone od Pallady, \\ Niegdyś Miasto ucieczką \\ Nasz ci Kraj, spiesz w te ślady ${ }^{7}$.}

Wspomnienie Aten, starożytnego centrum nauki i sztuki, oraz imienia patronki tego miasta - państwa, będącej wcieleniem rozumu, wzbogaca pochwałę centralnej postaci wiersza. Już w incypicie utworu nazwano Muzę „Mądrości Karmicielką”, która ,jak Matka życzliwa, / sama karmi sowicie". Zauważamy tu ścisły związek tej poetyckiej metafory z myślową zawartością tekstu ikonicznego przedstawiającego upersonifikowaną Poezję, który odnajdujemy w Iconologii Cesare Ripy (1593) - popularnym w XVII i XVIII wieku zbiorze zawierającym obrazy personifikowanych pojęć abstrakcyjnych. Autor odmalował Poezję (Poesia, Poetica) jako kobietę z odsłoniętą piersią. Podobne wyobrażenie pędzla Aleksandra Ubielewskiego, francuskiego malarza polskiego pochodzenia, znajduje się w zbiorze Cabinet des Beaux Arts (1690) prezentującym personifikacje sztuk. I tutaj również spotykamy Poezję jako rozmarzoną damę z odsłoniętą prawą piersią — symbolem płodności ${ }^{8}$. Misterną sieć znaczeń rozsnuł w swym wierszu autor. Twórca nie tylko wygłosił pochwałę Muzy, której

\footnotetext{
${ }^{6}$ Carmen Anacreonticum Graeco-Latinum. Toż polskim rytmem na skład podobny [b. m. druk. 1764], egz. Biblioteki Ossolineum we Wrocławiu, sygn. XVIII-7987-III.

7 Podobną formułę wzywającą siostry aońskie do bezzwłocznego przybycia w rodzinne strony „piewcy nieśmiałego” (tym razem jednak w celu rozsławienia „szczęśliwych ziem Rusi”), odnajdujemy m.in. u Klonowica: „Zacne tedy potomstwo Mnemozyne, Muzy, / teraz już w nasze pospieszajcie strony!”. (S. F. Klonowic, Roxolania. Roksolania czyli Ziemie Czerwonej Rusi, wyd. i przeł. M. Mejor, Warszawa 1996, s. 13).

${ }^{8}$ Por. W. Tatarkiewicz, Historia estetyki, t. 3: Estetyka nowvżytna. Warszawa 1991, s. 216. W tomie tym zawarto reprodukcje dwóch wspomnianych przeze mnie wyobrażen, które autor określa alegoriami, czemu zdecydowanie sprzeciwia się Jerzy Ziomek, Retoryka opisow'a, Wrocław 1990, s. 231, przyp. 6.
} 
natchnienie jest pokarmem dla poety (odnotujmy w tym miejscu, że wśród zabierających głos po elekcji apologetów, piewców Poniatowskiego niewielu dalekich było od tworzenia invita Minerva); nie tylko wskazał na Poezję dostarczającą duchowej uczty odbiorcom bogatych w sferze idei i form - wypowiedzi literackich. Autor przywołał ponadto obraz nowo obranego króla wychowanego na łonie mądrości ${ }^{9}$.

Powróćmy do przytoczonego powyżej porównania (comparatio), które podporządkowane zostało, oczywiście, amplifikacyjnym tendencjom wiersza. Warto dodać, że w łacińskiej wersji utworu zamieszczono następujące objaśnienie: „Sophiae. Sapientiae, more Poetico"10. Nieprzypadkowo przywołano tu antyczną koncepcję poezji — boskiej wiedzy dostępnej sługom Apollina. Cała wypowiedź bowiem, mimo że skierowana do mądrej Muzy, przynosi laudację Stanisława Augusta ukazanego w wierszu jako rex sapiens. W opinii autora jedynie ten wstępujący na tron monarcha („między królującymi mądrością wsławiony”) umożliwi helleńskiej patronce ludzi pióra — uważanej od starożytności za boginię władców i herosów - powrót na królewski dwór.

Należy zauważyć, że w analizowanym przez nas utworze wstęp zastąpiono na etapie inwencyjnym przedłożeniem (propositio) — rozbudowanym wprowadzeniem zmierzającym do jednego: do gloryfikacji Poniatowskiego. Utwór otrzymał postać wezwania, uroczystego zaproszenia skierowanego do córki Zeusa, aby przybyła w granice Rzeczypospolitej, gdyz wraz z wyborem Stanisława Augusta zakończył się „przykry” dla niej okres wygnania. Muza, zmuszona do opuszczenia Korony, winna — zdaniem poety — ponownie „spieszyć” do kraju, w którym władzę królewską dzierży w swych rękach opiekun „męży uczonych”. Pora zauważyć, że autor nie podaje bezpośredniej przyczyny opuszczenia polskiego Parnasu przez tę antyczną boginię. Nawet mało wnikliwe pochylenie się nad tekstem pozwala stwierdzić, że poeta nie upatrywał, jak to wydawać by się mogło, przyczyn jej milczenia w trwającym prawie rok burzliwym okresie bezkrólewia (choć to przecież inter arma silent Musae). Anonimowy laudator ukazał Poniatowskiego jako monarchę o niepospolitym umyśle, eksponując przede wszystkim jego wiedzę i wykształcenie. Autor widział w nim przyszłego protektora uczonych i poetów. Zauważamy więc, iż przywołanie antycznej bogini zapowiada uwznioślenie centralnej postaci wiersza, ku której nieznany bliżej „miłośnik muz” kicruje stale uwagę czytelnika. Carmen Anacreonticum - poetycka wypowicdź wzorowana na genus demonstrativum i podporządkowana wymogom retoryki laudacyjnej — przyjmuje więc formę panegiryku na

\footnotetext{
${ }^{9}$ Przypomnijmy, ze motyw ten pojawia się często w licznych, pisanych wierszem i prozą panegirykach wskazujących na mądrość i wykształcenie Stanisława Augusta. Zob. J. Pokora, Obraz Najjaśniejszego Pana Stanisław'a Augusta (1764-1770). Studium z ikonografii władzy, Warszawa 1993, s. 50-59.

${ }^{10}$ Zob. m.in. apologię poezji - nawiązującą do myśli antycznej, która wyszła spod pióra XVI-wiecznego teoretyka Antonia Marii de’Contiego: „Starożytni zaś, mówi Strabon, twierdzili, ze poezja jest jakby pierwszą filozofią [...]. Że zaś poezja (poetica) jest tym samym co i mądrość (sapientia) bądź filozofia, wskazuje także Arystoteles". (De arte poetica, cyt. za: E. Sarnowska-Temeriusz, Przeszloś' poetyki. Od Platona do Giambattisty Vica, Warszawa 1995, s. 266).
} 
część władcy. Cały tekst, mimo że skierowany do Muzy, przynosi laudację Stanisława Augusta - człowieka budzącego największe nadzieje na naprawę Rzcczypospolitej.

Dodajmy, że nie tylko okolicznościowi poeci powitali nowego monarchę jako osobę najbardziej na polskim tronie pożądaną. Panowanie mądrego króla ukazywano jako jedyną drogę prowadzącą do szczęścia obywateli. Dowodzą tego chociażby słowa wypowicdziane przez prymasa Władysława Łubieńskiego ósmego września w czasic ostatniej sesji sejmu elekcyjnego:

Palec Boży [...] osobliwie, że takiego podał nam Pana, o którego przezornej mądrości tak powszechną i ugruntowaną w Narodach Obydwóch mamy wszyscy opinię, a gdy na tronie przy nim mądrość niebieska berłem Jego zawsze władać będzie, niewatpliwie z mądrego rządu na całe królestwo szczęśliwości wypłyną $[\ldots]^{11}$.

Tego samego dnia marszałek Józef Sosnowski chyląc czoło przed Poniatowskim, przemawiał do rodaków:

[... nie mając na już tym tu placu więcej do czynienia, idźmy, a raczej ze skwapliwością spieszmy, jako niegdyś do Salomona z królów najmędrszego od ostatnich brzegów świata zbiegli się do oglądania wspaniałego oblicza i słuchania słodkich pieśni jego ${ }^{12}$.

U progu panowania Stanisława Augusta dostrzegamy więc znamienny fakt powszechnego ponaglania zarówno muz, jak i poddanych do złożenia hołdu nowemu monarsze.

Powróćmy do analizowanego tekstu, w którym autor nakazując helikońskiej bogini pośpiech przypomniał również o jej obowiązkach wobec władcy. Głównym, wyznaczonym już w starożytności, zadaniem tej „wsławionej Rodzicielki pochwał” było oczywiście rozsławianie królewskich przymiotów. Należy dodać, że chociaż anonimowy twórca Carmen Anacreonticum tworząc poetycki wizerunek Poniatowskiego przedmiotem pochwały uczynił przede wszystkim jego mądrość i wykształcenie ${ }^{13}$, to jednak w poprzedzającym główny tekst — napisanym po francusku — krótkim Envoi wskazał na niezwykłą osobowość króla:

Libre du prejugé vulgaire,

Je ne suis point allé, coupable téméraire

Dans le conseil des dieux dévoiler ces secrets;

"Diaryjusz sejmu electionis między usiq Wola a miastem Warszawą..., Warszawa 1764, k. Y.

12 Ibidem, k. X. 2.

${ }_{13}$ Por. Ode. Sonnet. Sonetto. Epigramma. [Na przyjazd Stanisława Augusta na Litwę], [Wilno], (Typ. Basilianis Vilnensibus) [po 1764]. Egz. Biblioteki Narodowej w Warszawie, sygn. W. 4173. Czytamy tam: „Dziś nowo obranego Króla wieńczy złota / Korona, w której stawa wdzięczna cnota:/ Na czele dziwna mądrość [...]". 
PRINCE, votre grande âme est leur vrai sanctuaire

Et c'est la que j'ai lu leurs augustes decrets ${ }^{14}$.

W dalszej części wiersza autor w trosce o godne przyjęcie Stanisława Augusta w przekonywający sposób zachęca Muzę do powrotu na służbę u króla:

Czas ci twarz wypogodzić

Po żałobnej zasłonie,

Z wdziękiem pierwszym przychodzić

U nóg składając skronie

Kształtem wdzięcznie pokornym

Czcząc KRÓLA i Obrońcę,

Który rządem przezornym

Słynie, gdzie ma bieg słońce.

Niegdyś łzami zalana

I mroźnym drżeniem wzięta

(Bądź miła ci odmiana)

Zrzuć te bojaźni pęta.

Zwróćmy uwagę, że nagromadzeniu (congeries) zwrotów odzwierciedlających niedolę przebywającej na obczyznie bogini („łzy”, „mroźne drżenie”, „żałobna zasłona”) ${ }^{15}$ towarzyszy wizja pomyślnej dla niej przyszłości („miła ci odmiana”). Autor zastosował w tej części wiersza jedną z figur myśli, parentezę (interclusio), chcąc silnej uwydatnić uczucie radości, jakie winno towarzyszyć Muzie z powodu poprawy jej losu. Córa Diosa - porównana do zatrwożonego wygnańca — ma, zdaniem poety, śmiało wkroczyć w granice Rzeczypospolitej, gdyż Poniatowski z chwilą objęcia tronu uchyla „ateńskie prawa”. Zastosowana tu metafora przywołuje starożytną instytucję sądu skorupkowego, który, przypomnijmy, w wyniku głosowania (ostracyzm) skazywał na wygnanie tego z obywateli, którego działalność uznano za szkodliwą dla ateńskiej demokracji.

${ }^{14} \mathrm{Z}$ okazji kolejnych polskich elekcji niejeden z twórców poetyckich wystąpień - utrzymanych w granicach topiki gloryfikującej - fabułę swych tekstów oparł na mitologii. Autor Carmen Anacreonticum nawiązał do znanego w literaturze okolicznościowej motywu narad olimpijskich bogów, którzy chcąc zakończyć interregnum wyznaczali na władcę najlepszego (najcnotliwszego) wśród śmiertelników. Utwory tego typu omawia szerzej Juliusz Nowak-Dłużewski (zob. m.in. tegoż, Polityczna poezja okolicznościowa w Polsce. Pienvsi królowie elekcyjni, Warszawa 1969, s. 46-47).

is Ten sam motyw - charakteryzujący okres oczekiwania na wybór króla jako czas ciemności i chaosu spotykamy też w innych poetyckich wypowiedziach powstałych z okazji ostatniej elekcji. Przywołał go m.in. w swym epinikionie Stanisław Pióro, starosta rumszyński. W podniosłym wstępie (noszącym cechy solemnitas) odnajdujemy motyw powiadomienia odbiorcy o „słodkiej, pożądanej nowinie” wraz z konstatacją: "Już też po smutnej, przeciagłej żałobie". ([S. Pióro], Plauz triumfalny $w$ czasie elekcyi nowego szczesstiwie obranego Najjaśniejszego Stanislawa Augusta Króla Jmśi polskiego. Najpierwej światu palemońskiemu $w$ stolecznym mieście J. K. Mści Wilnie w palacu Pióromoncie roku 1764 dnia $167^{\text {bra }}$ ogloszony. [Wilno, po 16 IX 1764]. Egz. Biblioteki Instytutu Badań Literackich Polskiej Akademii Nauk, sygn. XVIII.1.1998). 
Zauważmy, że autor nadał swemu poetyckiemu wystąpieniu kształt napisanej w podniosłym stylu pobudki - wezwania do przezwyciężenia bezpodstawnych obaw dręczących boginię. Zastosowana tu emocjonalna „retoryka odwagi” wynika z nadrzędnej tendencji wypowiedzi. Poeta bowiem - przez wykorzystanie Homeryckiego wzorca nakłaniającego Muzę do określonych działań ${ }^{16}$ — zwracał się jednocześnie ku szerszemu audytorium ${ }^{17}$. U progu panowania Poniatowskiego rola nadawcy panegirycznego utworu sprowadzała się do nakłonienia zbiorowości szlacheckiej do zaakceptowania królewskiej polityki, a tym samym do pozbycia się nieuzasadnionego lęku poddanych o dalsze losy Rzeczypospolitej ${ }^{18}$. Autor przekonuje odbiorców, że „KRÓL”

Którego w tym sława

Bronić Męże uczone,

Władnąć w wolnym Narodzie

Nauki wyzwolone

By w swej były swobodzie

jest najodpowiedniejszą osobą do sprawowania władzy; przekonuje, że ten, któremu powierzono koronę, będzie najlepszym opiekunem nauki i sztuk.

Dodać należy, że wizję ponownego odrodzenia państwa zapowiada obecna w wierszu antynomia światła i ciemności ${ }^{19}$. Anonimowy poeta wykorzystał charakterystyczną dla elekcyjnego tekstu topikę ( $z$ motywem wschodzącego słońca) uczestniczącą w kształtowaniu pochwały mądrości człowieka obejmującego polski tron. Dość przytoczyć tu - tytułem przykładu - te oto słowa skierowane do Muzy towarzyszącej Apollonowi, pod którego imieniem „rozumie się słońce" ${ }^{20}$ :

Dla ciebie grunt nadzieje,

Iz w wschodzie tego słońca

Znać było, że jaśnieje

Mądry Mądrych Obrońca.

\footnotetext{
${ }^{16}$ Szerzej na ten temat J. Brzozowski, Muzy w poezji polskiej. Dzieje toposu do przelomu romantycznego, Wrocław 1986, s. 90

${ }^{17}$ Różnorodne typy układu nadawczo-odbiorczego oświeceniowej ody omawia Teresa Kostkiewiczowa, Oda w poezji polskiej. Dzieje gatunku, Wrocław 1996, s. 163-224.

18 Przywołajmy tu wypowiedź zamieszczoną w najnowszej monografii króla: „[...] w propagandzie prowadzonej przez Stanisława Augusta to dopiero czasy jego panowania miały być początkiem «nowego świata tworzenian". (K. Zienkowska, op. cit., s. 54).

${ }_{19}$ Problematykę tę omówimy szerzej w dalszej części.

${ }^{20}$ M. T. Cicero, O naturze bogów, ks. 2 rozdz. 27 i 68 [w:] tenże, Pisma filozoficzne, t. 1, przeł. W. Kornatowski, Warszawa 1960, s. 112. Jadwiga Bednarska opisując wyobrażenia Muzagetesa wraz z towarzyszącym mu orszakiem dziewięciu Muz przypomina, że Apollon był „bogiem słońca w etycznym i duchowym rozumieniu". (J. Bednarska, $Z$ dziejów polskiej ilustracji panegirycznej pierwszej polowyXVII wieku. Motywy i tematy antyczne w polskiej panegirycznej ilustracji ksiqżkowej. Studitum z zakresu ikonografii sztuki nowożytnej, cz. 1, Katowice 1994, s. 93, przyp. 16).
} 
Autor rozsnuł w wierszu wizję pomyślnej przyszłości. „Wschodzące słońce” bowiem to zapowiedź nadejścia lepszych czasów, ponownych narodzin Rzeczypospolitej Obojga Narodów. Dodajmy jeszcze, że tematyka solarna była przez cały okres panowania Poniatowskiego wykorzystywana skwapliwie przez jego apologetów ${ }^{21}$.

Zadaniem antycznych muz było dodawanie splendoru doniosłym wydarzeniom. Wtórując formindze Muzagetesa uświetniały one uczty antycznych bogów. W Carmen Anacreonticum przywołano córę Diosa w celu wskazania na doniosłość momentu historycznego. Ma ona śpiewem i grą na różnych instrumentach sławić przymioty króla-herosa. Muza więc zostaje przez poetę wezwana do „zwykłej swojej roboty” (zwrot ten — w celach amplifikacji zostanie jeszcze powtórzony):

Zbierz wiersze, dźwięki, pienia,

Harfy, cytry i lutnie.

Pochwały słodkie brzmienia

Tu sprowadź, a nie smutnię.

Autor kilkakrotnie wymienia różnorodne atrybuty, przypominając jej o „strunach” i „śpiewaniu” 22 , a wszystko po to, aby helikońska bogini — „wspomniawszy sobie / słodkie wdzięku przymioty” — służyła „ozdobie KRÓLA”. Widzimy więc, że XVIII-wieczny poeta, podobnie jak jego starożytny poprzednik, pamiętał o tym, że słowu wiązanemu, aby osiagnęło zamierzony cel, towarzyszyć musi śpiew lub melodia instrumentalna. Dopiero wówczas bowiem, gdy poezja i muzyka (wraz z tańcem) tworzyć będą nierozerwalną całość (ode teleia $^{23}$, wiersz włączony zostanie w krąg tradycji heroicznej twórczości, a czytelnik wprowadzony tym samym w odwieczny świat epopei. Topos muz, jak pisze Brzozowski, miał przez wieki

\footnotetext{
21 Adam Naruszewicz — zwolennik królewskiego obozu reform — był jednym z twórców, który wykorzystywał w swej twórczości panegirycznej metaforykę solarną. Szczegółową analizę jej różnorodnych wariantów w poetyckim dorobku księdza biskupa przeprowadza Barbara Wolska, W świecie żyviotów, Boga i czlowieka. Studia o poezji Adama Naruszewicza, Łódź 1995, s. 86-140. Chociaż analiza królewskiego mitu solarnego nie jest celem tego szkicu, warto zwrócić uwagę na brak powiązań instytucji wolnej elekcji z idealnym państwem słonca stworzonym przez Tomasza Campanellę. Wspomina o tym Janusz Tazbir, (op. cit. , s. 25).

${ }_{22}$ Wezwanie typu ,reiner Musenanruf" (takie określenie formuly skierowanej do Muzy podaję za Brzozowskim, op. cit. , s. 106-107) spotykamy w utworach pisanych na cześć wcześniejszych polskich władców. Przypomnijmy chociażby ten oto początkowy fragment barokowego utworu napisanego z okazji koronacji Jana III Sobieskiego:

Król jedzie, muzy! Do lutni, do cyter!

Niechaj się każda z was sztuką pisze!

Co instrumentów, co pieśni, co liter,

Witajcie nowe na niebie Jowisze!

(W. Potocki, Muza polska na tryjumfalny wjazd Najjaśniejszego Jana III, wyd. A. Karpiński, Warszawa 1996, s. 13). 23 Por. A. M. Komornicka, Simonides z Keos. Poeta i mędrzec, Wrocław 1986, s. 21-32; taż, Poezja starożytnej Grecji. Wybrane gatunki literackie, Łódź 1987.
} 
[...] bardzo często charakter ornamentu czy ozdoby. Byl - skonwencjonalizowanym i monotonnie ponawianym elementem poetyckiej wypowiedzi. Ale [...] jednocześnie odzwierciedlał i tę prawdę, że zadaniem, sensem, celem, istotą poezji jest chwalić i unieśmiertelniać pewne fragmenty „historii świata”. Jest — innymi słowy - ujmować je w formę pieśni, wyrażać przez pieśń. I tutaj — właśnie wszechobecny, właśnie ponawiany natrętnie i z uporem przy każdej po temu okazji — jawi się jako wyraz niezachwianej i trwałej wiary [...] w sens poezjowania ${ }^{24}$.

Zwróćmy uwagę na bodaj czy nie najważniejsze przesłanie plynące z tekstu powstałego w okresie, który poprzedzał bezpośrednio czas rozstania poetyckich twórców przełomu romantycznego z klasyczną Muzą. Z analizowanego przez nas wiersza nazwanego pieśnią (na co wskazuje tytuł: carmen) wyłania się wizja poezji jako boskiej mowy; poezjowania jako sztuki. Skonwecjonalizowany w dużej mierze nurt poezji okolicznościowej pozbawiony był głębszych refleksji, autorzy literackich wypowiedzi — budując pochwałę władców - sięgali głównie po tradycyjne schematy fabularne, motywy i wątki. Na tym tle za wyjątkowy należy uznać omawiany wiersz. Autor przywołujący antyczny wzorzec - literaturę starożytnych Hellenów - przedmiotem pochwały uczynił język polski; dodajmy raz jeszcze, że twórcy prozą i wierszem pisanych panegiryków elekcyjnych to zagadnienie pomijali. Poeta natomiast z podziwem i uznaniem przedstawił greckiej Poezji jej polską „siostrę”. Pisząc o zaletach ojczystej mowy wskazał na łączące je więzi pokrewieństwa:

Tobie i polska mowa,

Kształtem cudnie ozdobna,

Zjednać przystęp gotowa

Wszystkim siestrze podobna

Kształtem, barwą szkarłatną

I twarzy ułożeniem,

I gładkością udatną,

I słów pieszczonych brzmieniem,

I powagą i torem

Umiarkowanym śladu

Idąc języków wzorem

Cnych, podług swego składu.

I w tym fragmencie przywołuje twórca - wspomniane już wcześniej — upersonifikowane wyobrażenia Poezji (Ripy i Ubielewskiego). Pora więc przyjrzeć się im uważniej. Obie o twarzach pięknych i zamyślonych ukazane są z wieńcem laurowym - atrybutem muz. Różnica polega na tym, że u Ripy Poezja stojąc, trzyma w jednej ręce lirę, a w drugiej flet;

\footnotetext{
${ }^{24}$ J. Brzozowski, op. cit., s. 118-119.
} 
Ubielewski natomiast przedstawił kobietę siedzącą w towarzystwie putti opiekujących się jej atrybutami. Widzimy więc, jak bardzo bliski był tym wcześniejszym, plastycznym przedstawieniom literacki obraz, który wyszedł spod pióra XVIII-wiecznego twórcy.

Podkreślmy raz jeszcze, iż rzeczą niezwykle ważną jest to, że Carmen Anacreonticum przenika świadomość wielkości „polskiej mowy”, dorównującej swej starszej „siostrze” kunsztownością, swobodą, muzycznością, potoczystością i czystością składni. Autor — przekonany, iż tylko piękna i czysta polszczyzna — bez „makaronizmów”, które „wiersz szpecą”,25 — jest w stanie udźwignąć wielką epikę ${ }^{26}$, włącza się w nurt odnowy języka polskiego. Poecie stojącemu w jednym szeregu w obronie czystości i jasności polskiej sztuki pisania z Józefem Aleksandrem Jabłonowskim czy Stanisławem Konarskim, bliska zapewne byłaby też refleksja Franciszka Ksawerego Dmochowskiego, którą teoretyk poezji zamieścil w Sztuce rymotwórczej, wydanej ponad dwadzieścia lat po ukazaniu się omawianego przez nas utworu: „Długo mowa ojczysta w małej była cenie / Jako do pism niezdolna. Szczęśliwe natchnienie / Oświeciło nas z czasem”27. Autor klasycystycznej poetyki stawia dalej w jednym rzędzie Jana z Czarnolasu i Stanisława Augusta Poniatowskiego, pod którego „mądrym berłem”

Znowu pierwsza Muz polskich powróciła sława.

(I 271-273, 298)

Oczywiście, celom amplifikacyjnym podporządkowane zostało przywołanie obok Kochanowskiego również nazwisk innych twórców, którzy zdaniem autora przyczynili się do rozkwitu rodzimego Parnasu. Zauważmy jednakże, że Dmochowski wypowiada się z uznaniem o wkładzie króla w rozwój polskiej nauki oraz o opiece, jaką otacza on ludzi sztuki ${ }^{28}$, natomiast autor Carmen Anacreonticum - utworu, w którym również dostrzegamy silną tendencję panegiryczną — dopiero te monarsze poczynania zapowiada.

Motyw patrimonium scientiae, który wielokrotnie powracał w „królewskiej” poezji, odezwał się nie tylko w tekstach powstałych u progu panowania Poniatowskiego, ale również w okresie późniejszym ${ }^{29}$. Dodajmy przy okazji, że do kręgu twórców, którzy podejmując temat

${ }^{25} \mathrm{~J}$. A. Jabłonowski, Nauki o wierszach i wierszopiszcach polskich (Lwów 1751). (Cyt. za: Oświeceni o literaturze. Wypowiedzi pisarzy polskich 1740-1800, opr. T. Kostkiewiczowa i Z. Goliński, Warszawa 1993, s. 57).

${ }_{26}$ Refleksja o polskim języku artystycznym bliska jest twórcom kolejnych epok. Oto fragment wypowiedzi Henryka Sienkiewicza z końca XIX wieku: „[...] ta mowa niepożyta jak spiż, świetna i droga jak złoto, jedna z najwspanialszych w świecie, tak wspaniała, piekna i wdzięczna, że chyba tylko język Hellenów może się z nią porównać." (Cyt. za: Z. Kubiak, Eneida, lódeczka na morzu, [wstęp do:] P. Wergiliusz Maro, Eneida, przeł. i opr. Z. Kubiak, Warszawa 1998, s. 40). Zob. też M. Klimowicz, Walka o jezzk narodowy, [w:] tenże, Oświecenie, Warszawa 1998; Z. Kloch, Spory o jezyk, Warszawa 1995.

${ }_{27}$ F. K. Dmochowski, Sztuka rymotwórcza, opr. S. Pietraszko, Wrocław 1956 (BN I 158), s. $24,27$.

${ }^{28}$ Ignacy Krasicki pisząc o poczynaniach polskich władców zmierzających do podniesienia poziomu rodzimej nauki, stwierdził: „sprawiedliwie zasłużył na imię wskrzesiciela Stanisław August”. (I. Krasicki, Uwagi, wst. i opr. Z. Libera, Warszawa 1997, s. 238).

${ }_{29}$ Zob. na ten temat m.in. J. Platt, Stanislaw August jako opiekun poetów i uczonych w twórczości „Zabaw Przyjemnych i Pożytecznych", „Wiek Oświecenia" t. 4: Z historii sztuki, literatury i idei, Warszawa 1984, s. 39-66; Z. Libera, Stanistaw August Poniatowski - opiekun i mitośnik literatury, [w:] Życie kulturalne i religijność w czasach 
elekcji czy koronacji, wyrażali nadzieję, że w osobie nowego władcy zyskała Koróna protektora nauk i sztuk, należał ojciec Giovanni Brunati. Oprawę muzyczną do jego Cantata a tre voci $^{30}$ przygotował Mattia (Mathias) Gherardi (Gerardi, Girardi), który w dniu koronacji pełnił już obowiązki kapelmistrza Jego Królewskiej Mości Króla Polski ${ }^{31}$. W tym udramatyzowanym utworze, w którym wprowadza autor postaci bóstw antycznych (Apollina, Temidę) oraz upersonifikowaną Sarmację, wykorzystano typową dla nurtu poezji okolicznościowej figurę - prozopopeję. O charakterze całości decydują tu - bogate w hiperbole - wypowiedzi laudacyjne. Autor w usta samego Apollina włożył te oto słowa: „Esso de studi amiche / Le Muse attirera nel sto soggiorno” („On jest przyjacielem nauki / i Muzy zaprosi do swej siedziby"). Temida z kolei czyni z Poniatowskiego konkurenta olimpijskiego boga:

Poco sarebbe Apollo

Se le bell' arti sole

Ele Muse gentili

Nel Sarmatico suol fiorir facesse.

[Zazdrość zapłonie w sercu Apolla

Gdy namiętne Sztuki Piękne

i Pieśni urocze

na sarmackiej zakwitną ziemi.]

Pora już powrócić do tekstu będącego głównym przedmiotem naszego zainteresowania - do wiersza o Muzie, Poezji i... Sławie, która - w opinii anonimowego laudatora podobnie jak helikońska bogini, była również przez długi czas nieobecna przy polskim tronie. Zaciekawia tu szczególnie zastosowanie jednego z wariantów obecności Muzy w dziele poetyckim; wariantu ukazującego boginię jako poddaną króla „upadłą u jego stóp”. W momencie składania hołdu spotyka ona upersonifikowaną Sławę, która, jak zapewnia poeta, "dźwignie” ją swą „nicwzruszoną ręką". ()d tej pory, zdaniem autora, Muza i Sława staną się nierozłączną parą w służbie króla. Zlączỵł je bowiem wspólny cel: wyśpiewanie przymiotów władcy i doniesienie o nich całemu światu, gdyż jego czyny godne będą wiecznej pamięci. Wybór postaci Muzy i upersonifikowanej Sławy nie jest oczywiście przypadkowy. Każda z nich, powróciwszy w granice Rzeczypospolitej, ma sławić wybranego przez naród króla i nową epokę, która nadchodzi wraz z przejęciem przez niego rządów. Te poetyckie zabiegi, choć interesujące, tworzą jednak zjawisko przesadnego panegiryzmu, który rozwinął się właśnie na gruncie generis demonstrativi.

Stanistawa Augusta Poniatowskiego, red. M. M. Drozdowski, Warszawa 1991, s. 85-99.

${ }^{30} \mathrm{G}$. Brunati, Cantata a tre voci per festeggiare il giorno della coronazione di S. M. Stanislao Augusto Re de Polonia, Warszawa 1764. Egz. Biblioteki Gdańskiej Polskiej Akademii Nauk, Mfm neg. sygn. 1171.

${ }^{31}$ Obraz kultury muzycznej w kręgu królewskiego mecenatu Stanisława Augusta przedstawia Alina Żórawska-Witkowska, Muzyka na dworze i w teatrze Stanistawa Augusta, Warszawa 1995. 
Dodajmy jeszcze, że w zamykającej utwór peroracji zgodnie z regułami topiki laudacyjnej przywołano popularny w panegirycznej poezji okolicznościowej motyw origo gentis. Autor przypominając imię Stanisława Poniatowskiego — seniora, „Ojca Najzacniejszego”, kasztelana krakowskiego, eksponuje tylko jedną z jego zalet. Dostrzega w nim bowiem jedynie (!) „mądrością pierwszego w gronie obrad".

Uczynienie w wierszu przedmiotem pochwały mądrości i wykształcenia (zarówno nowego monarchy, jak i jego rodzica) nie jest przypadkowe. Pod piórem anonimowego twórcy dokonuje się swoista apoteoza króla. Ta poetycka wypowiedź przedstawia bowiem obraz Poniatowskiego zgodny z oświeceniowym wizerunkiem idealnego władcy. Panowanie Stanisława Augusta przypadło na Wiek Rozumu i zgodnie z panującą wówczas opinią tylko rządy mądrego monarchy mogły gwarantować szczęście obywateli. Carmen Anacreonticum przynos: więc — nie pozbawiony elementów idealizujących — portret człowieka wykształconego, pod którego berłem polska nauka i sztuki doznają opieki.

Panegirycznej intencji wiersza - opartej na tradycyjnej topice laudacyjnej — służyły też występujące w nim antynomie, o których wspomnieliśmy powyżej, sygnalizując tylko odwołania do symboliki solarnej. W opinii autora ciemność i smutek to reprezentatywne cechy polskiej rzeczywistości bez Poniatowskiego — króla, natomiast jasność i wesele staną sį̧ udziałem poddanych Stanisława Augusta — władcy, który uczyni z Rzeczypospolitej siedzib̨̧ Muzy i boskiej Ateny. Dodajmy, że antynomia: światło-ciemność zawiera w sobie antyczno-biblijne konotacje. Przywołuje bowiem obraz Stwórcy wypowiadającego w momencic stworzenia imperatyw: „Niech się stanie światłość!”. Podobnie z ciemności-chaosu, w którym pogrążona była Rzeczypospolita, wyłania się światło-harmonia i porządek, któregc zwiastunem są elekcyjne obrady. Jest tu też zawarty — zbudowany z aluzji do mitologii obraz jasności następującej po mrokach nocy. Ten dualistyczny obraz przywołany zosta w wierszu nieprzypadkowo - stanowi bowiem wizję ponownych narodzin polskiego państwa. Zauważmy, że „zasłona żałoby” (którą przywdziała Muza), symbol smutku — to znak przeszłości, natomiast teraźniejszość jest radosna, a jej symbolem jest „wschodzące słońce” którego promienie zachęcą helikońskie boginie do przybycia. Aurora Musis amica. Czyż tc właśnie wczesna pora - tu oznaczająca początek panowania króla, z którym wiązano tak wielkie nadzieje — nie sprzyjała natchnieniu?

Analizowany tekst jest jednym z nielicznych panegirycznych wierszy okolicznościowych w których zawarto metapoetyckie refleksje. Anonimowy autor, idąc śladami poprzednikón w ich namyśle nad sztuką poezjowania, łączył pojęcie poezji (wiedzy) z pojęciem natchnienia Taka koncepcja twórczości poetyckiej była głęboko osadzona w tradycji grecko-rzymskiegc antyku. Polski twórca przypomniał czytelnikowi, że poezja — wraz z muzyką i tańcem stanowi zewnętrzny przejaw natchnienia muz, jest ich fizycznym odzwierciedleniem ${ }^{32}$.

${ }^{32}$ Por. A. M. Komornicka, op. cit., s. 21. 
Nie zapominajmy na koniec o tym, że Carmen Anacreonticum należy do tego nurtu prokrólewskiej poezji panegirycznej, który nawiązuje do tradycyjnego wzoru radosnego wiersza okolicznościowego ${ }^{33}$. Poeta w chwili tak ważnej dla narodu nie chce pozostać osamotniony. Wzywa więc helikońskie boginie, Poezję i Sławę, aby dzieląc jego szczęście, opiewały przymioty nowo obranego władcy. „Muza bowiem nie da umrzeć mężom godnym chwały".

${ }^{33}$ Zob. T. Kostkiewiczowa, Staumi poeci polscy XVIII wieku wobec Konstytucji 3 Maja, [w:] „Rok Monarchii Konstyttucyjnej". Piśmiennictwo polskie lat 1791-1792 wobec Konstytucji 3 Maja, red. T. Kostkiewiczowa, Warszawa 1992, s. 29-51. 